\title{
KONSEP PENCOBAAN MENURUT YAKOBUS 1:12-15
}

\author{
Hiskia Gulo \\ Sekolah Tinggi Teologi Soteria Purwokerto \\ hiskiagulo27@gmail.com
}

\begin{abstract}
Abstrac. The life of a believer is never free from various temptation in the form of challenges and problems. This makes it difficult for some believers to understand the meaning of temptation. Some even think that temptation are caused by God. This study aims to explain about temptation according to James 1: 12-15. The method used is a syntactic and semantic text analysis approach, which is to focus on the text itself and connect with other texts. The results showed that based on James 1: 12-15, temptation does not come from God but in humans themselves because they are dragged into by sin. But those who are able to withstand the trials of trials will grow to a perfect and holy life with God.
\end{abstract}

Keywords: Temptation, James 1:12-15, God, Believers

\begin{abstract}
Abstrak. Kehidupan orang beriman tidak pernah luput dari berbagai pencobaan berupa tantangan dan permasalahan. Hal ini membuat sebagian orang percaya sulit memahami makna pencobaan. Bahkan ada yang menganggap pencobaan disebabkan oleh Allah. Penelitian ini bertujuan untuk menjelaskan tentang pencobaan menurut Yakobus 1:12-15. Metode yang di gunakan adalah pendekatan analisis teks secara sintaksis dan semantis yaitu fokus pada teks itu sendiri dan dihubungkan dengan teks-teks lainnya. Hasil penelitian menunjukkan bahwa berdasarkan Yakobus 1:12-15, pencobaan tidak berasal dari Allah tetapi dalam diri manusia itu sendiri karena terseret oleh dosa. Namun orang yang sanggup bertahan dalam ujian pencobaan akan bertumbuh kepada kehidupan yang sempurna dan kudus bersama dengan Allah.
\end{abstract}

Kata Kunci: Pencobaan, Yakobus 1:12-15, Allah, Orang Percaya

\section{PENDAHULUAN}

Kehidupan setiap umat manusia tidak pernah lepas dari pencobaan.

Pencobaan kerap kali di kaitkan dengan berbagai tantangan, penderitaan, musibah bahkan semua hal yang membuat kehidupan umat manusia kehilangan kebahagiaan dan sukacita. Akibatnya banyak orang menganggap pencobaan sebagai sesuatu yang buruk dan harus di hindari. Bahkan ada yang menganggap 
bahwa pencobaan berasal dari Allah. Meskipun, seperti dikatakan Wiersbe, Allah tidak pernah mencobai siapa pun sebab Dia kudus. (Wiersbe 1999). Kesalahpahaman seperti ini membuat banyak orang percaya gagal bahkan menyerah ketika menghadapi pencobaan dan ujian iman.

Kenyataan ini mendorong penulis ingin meneliti konsep pencobaan menurut Yakobus 1:12-15. Di sini Yakobus menyatakan bahwa pencobaan dapat menjadikan iman orang percaya bertumbuh dewasa melalui ketekunan, kesabaran, tahan uji serta mendapat kemenangan dan kesempurnaan hidup di dalam Yesus Kristus.

Pencobaan adalah sesuatu yang positif. Gulo mengatakan bahwa pencobaan dapat mendatangkan kehidupan yang lebih mendekatkan pada kesempurnaan dengan kebahagiaan, kemenangan dan keindahan rohani. (Gulo 2017). Tentu saja, seperti dikatakan Jura, pencobaan tidak akan menggoyahkan seseorang dengan iman yang teguh. (Jura 2017). Orang berhikmat akan sabar dan tekun terhadap segala ujian sehingga menghasilkan kedewasaan rohani yang membuat dia semakin terus bertumbuh menjadi serupa dengan Kristus (band. Yak. 1:2-5). (Arifin 2019).

Hal yang ingin digali dari konsep pencobaan menurut Yakobus 1:12-15 adalah benarkah Allah berada di balik setiap pencobaan dan ujian yang dialami oleh setiap orang percaya? Harapannya tulisan ini bermanfaat bagi para pembaca agar lebih termotivasi untuk memahami dan merespon setiap pencobaan dan ujian iman dengan sabar dan tekun sehingga dapat menuju kesempurnaan serta keindahan rohani bersama dengan Allah. 


\section{METODE PENELITIAN}

Sumber Yakobus 1:12-15 akan diambil dari The Greek New Testament Nestle-Aland 28th Edition of the Greek New Testament. Kajian akan menggunakan metode eksposisi yaitu menguraikan atau memaparkan teks untuk menemukan semantic content (isi semantis atau makna spiritual dibalik teks atau Theoria) di dalam teks-teks tersebut, fokus pada teks itu sendiri, dan berinteraksi dengan teks-teks lain yang berhubungan semantis atau makna. Semantic Content dibangun dari historia dengan cara membuat syntactic form (struktur teks dalam bahasa Yunani) dan terjemahan literal untuk mendapatkan poin-poin sintaksis. Selanjutnya poin-poin sintaksis akan dianalisis ke dalam semantic content dihubungkan dengan teks-teks lain di dalam Alkitab. Kemudian kajian di dalam semantic content akan diringkas atau dirumuskan menjadi konsep teologis (personal). Seperti dikatakan Hendi, konsep teologis ini adalah doktrin atau ajaran yang ditemukan dan kemudian akan dibuat relevansi atau aplikasinya bagi kehidupan spiritual orang percaya berdasarkan doktrin tersebut (obedience). (Hendi 2019).

\section{HASIL PENELITIAN}

\section{Historia: Data Teks, Syntactic Form}

Hasil penelitian terhadap Yakobus 1:12-15 dengan menggunakan syntactic form adalah sebagaimana tertuang pada bagan berikut ini: 
Ayat. 12

Maкápios
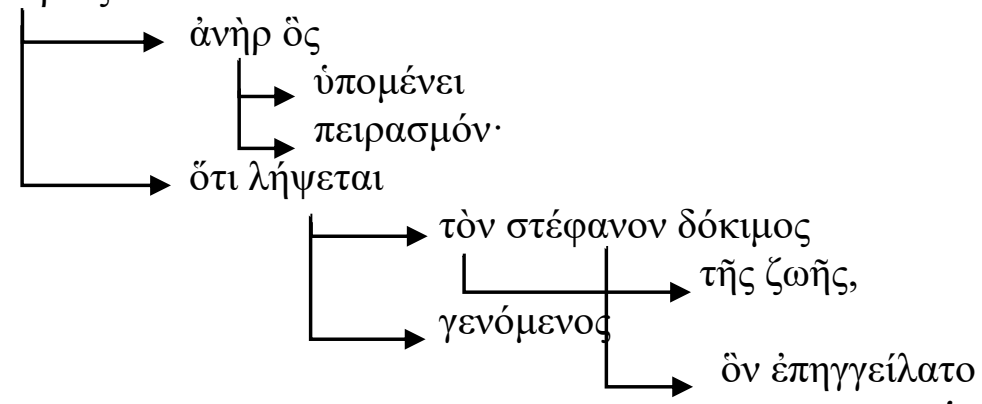

Ayat. 13

$\pi \varepsilon 1 \rho \alpha \zeta o ́ \mu \varepsilon v o \varsigma$

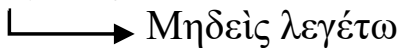

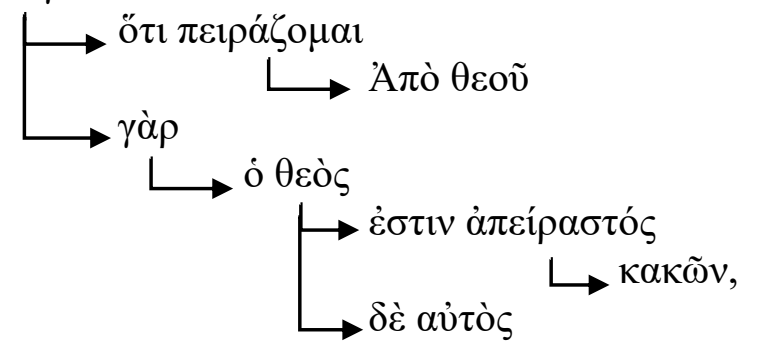

Ayat. 14

$\longrightarrow \pi \varepsilon 1 \rho \alpha ́ \zeta \varepsilon 1$ o $\delta \varepsilon \dot{v} v \alpha$

$\delta \grave{\varepsilon} \varepsilon \check{\kappa} \alpha \sigma \tau ం \varsigma$

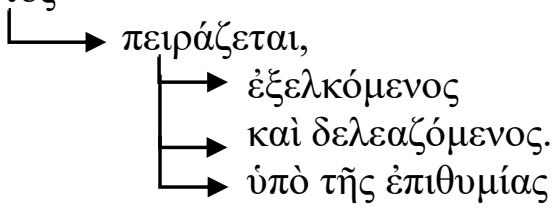

Ayat. 15

$\longrightarrow$ idías

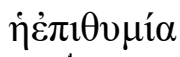

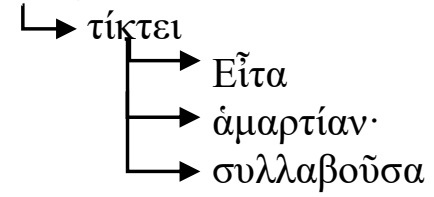

$\dot{\eta} \dot{\alpha} \mu \alpha \rho \tau i ́ \alpha$

$\longleftrightarrow \dot{\alpha} \pi$

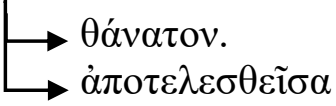




\section{Terjemahan Literal}

${ }^{12}$ Allah akan membahagiakan umat-Nya yang tetap setia kepada-Nya di tengah ujian yang dihadapi karena ketika mereka berhasil melewati ujian tersebut, Allah telah berjanji bahwa Dia akan memberikan kehidupan kekal sebagai sebuah hadiah. Inilah yang Allah akan berikan kepada mereka yang mengasihi Dia. ${ }^{13}$ Janganlah seorang pun berkata ketika dia mengalami pencobaan untuk berbuat jahat, "Allah sedang mencobai aku untuk berbuat jahat." Karena Allah sendiri tidak dapat dicobai untuk berbuat jahat dan Dia sendiri tidak pernah mencobai siapapun untuk berbuat jahat.

12 Allah akan membahagiakan umat-Nya yang tetap setia kepada-Nya di tengah ujian yang dihadapi karena ketika mereka berhasil melewati ujian tersebut, Allah telah berjanji bahwa Dia akan memberikan kehidupan kekal sebagai sebuah hadiah. Inilah yang Allah akan berikan kepada mereka yang mengasihi Dia. 13 Janganlah seorang pun berkata ketika dia mengalami pencobaan untuk berbuat jahat, "Allah sedang mencobai aku untuk berbuat jahat." Karena Allah sendiri tidak dapat dicobai untuk berbuat jahat dan Dia sendiri tidak pernah mencobai siapapun untuk berbuat jahat

14 Tetapi seseorang dicobai ketika dia tertarik dan tergoda oleh keinginan jahatnya sendiri. ${ }^{15}$ Kemudian ketika keinginan jahat itu dibuahi, dia melahirkan perbuatan jahat, dan ketika perbuatan jahat itu selesai dilakukan, dia melahirkan kematian.

\section{PEMBAHASAN}

Theoria: Semantic Content

Semantic Points (Penjelasan setiap ayat) 
Ayat 12 diawali dengan kata Makápıoৎ sehingga ini menunjukkan sebuah konklusi yang dituliskan oleh Yakobus kepada jemaatnya yang bertahan, tabah, yang setia kepada Tuhannya. Dalam bertahan, orang itu sendiri mengalami kebahagian tersendiri di dalam jiwanya. (Widjana 1995). Yakobus menyatakan, "Berbahagialah orang yang tahan uji" (Ayat 12). Artinya pencobaan itu tidak harus berujung pada dosa. Ada pencobaan yang berujung pada mahkota kehidupan. Ini terjadi jika orang bertahan dan menolak daya tarik kejahatan. Mahkota kehidupan diberikan Allah sebagai bukti bahwa orang tersebut setia mengasihi Allah. Pemberian makhkota kehidupan adalah berdasarkan dua hal dalam ayat ini, yaitu bertahan dan mengasihi Allah. (Gunning 2009).

Selanjutnya dikatakan $v \pi o \mu \varepsilon ́ v \varepsilon ı ~ \pi \varepsilon 1 \rho \alpha \sigma \mu o ́ v$ yang berarti bertahan atau tahan uji dalam pencobaan. Dalam teks ini kata Peirasmos mengandung dua arti. Pertama, kata ini berarti "ujian" (ayat 12; bandingkan terjemahan Lembaga Alkitab Indonesia [LAI] yang menerjemahkannya dengan kata "pencobaan.") karena diikuti oleh verba Hupomenw. Ujian di sini maksudnya berbagai macam kesulitan dari luar. Kedua, kata ini juga berarti "pencobaan" (ayat 13-15) yang berasal dari dalam diri sendiri untuk melakukan perbuatan jahat. (Hendi 2015). Dalam hal ini kata pencobaan dalam ayat 12 di pakai dalam bentuk tunggal (bukan jamak seperti di ayat. 2), yang berarti bahwa di sini lebih ditekankan manusia yang dicobai daripada pencobaan yang mencobai (Wiersbe, 1999). Pencobaan dalam ayat ini mengacu kepada berbagai masalah atau peristiwa atau keadaan yang Tuhan izinkan terjadi dengan hendak menguji iman seseorang sehingga diperteguh kerohaniannya serta bertumbuh menuju kesempurnaan. 
Dalam ayat 13 Yakobus dinyatakan bahwa dalam setiap ujian orang percaya mungkin saja bisa gagal. Namun Yakobus dengan tegas menyatakan bahwa pencobaan bukan berasal dari Allah. Kata yang dipakai adalah $\pi \varepsilon 1 \rho \alpha \zeta o ́ \mu \varepsilon v o \varsigma$ verb participle present passive yang menunjuk pada pencobaan yang berasal berasal dari diri sendiri dan terus menerus ada. Sebagaimana sudah dijelaskan bahwa pencobaan merupakan berbagai masalah, kejadian atau keadaan yang Tuhan izinkan terjadi dengan maksud hendak menguji iman seseorang. Tetapi pencobaan dapat juga merupakan godaan dari iblis yang di dukung oleh keinginan yang pada dasarnya sudah di cemar oleh dosa. (Scheunemman 2013).

Kedua hal ini merupakan Peirasmos yang dihadapi oleh jemaat. Datangnya godaan tidak langsung mendatangkan berkat. Pengalaman digoda sebenarnya mengandung resiko. Namun demikian, jika seorang bertahan (bandingkan dengan ketahanan, ayat 3), maka ia menjadi orang yang tahan uji. (Susanto 2009). Dengan pembuktian bahwa Allah sendiri tidak dapat di cobai oleh yang jahat sebab Allah juga tidak dapat mencobai siapa pun. Pencobaan tidak pernah datang dari Allah karena Dia senantiasa memikirkan, memberikan, dan menganugerahkan yang terbaik bagi setiap manusia.

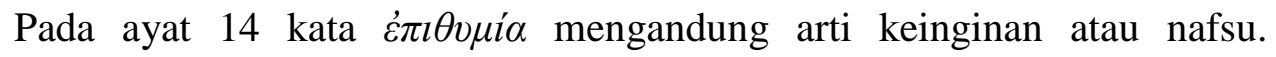
Pemicunya adalah keinginan diri yang terseret dan terpikat hingga berujung pada dosa. Sesuatu menjadi godaan bagi seseorang apabila dia diseret dan dipikat oleh keinginan atau hawa nafsunya sehingga menjadi keinginan berdosa dalam diri setiap manusia. Yang dimaksud dengan keinginan di sini adalah keinginan yang berada di luar kehendak Tuhan. Keinginan atau hawa nafsu itu mengandung arti 
dibuahi oleh satu hal yang memikatnya; sebagai akibatnya lahirlah dosa. Kalau dosa sudah itu sudah dewasa atau matang, ia melahirkan maut (bnd. 1 Korintus 15:56; Roma 7:5-12; Matius 18:7-9). (Scheunemman 2013). Kata dibuahi berarti dibiarkan melangkah lebih lanjut, tidak dikekang atau dikendalikan tetapi dituruti sehingga terjadilah perbuatan dosa yang melahirkan maut.

Pada ayat 15 berujung pada kata $\tau i k \tau \varepsilon l ~ \dot{\alpha} \mu \alpha \rho i ́ \alpha v$ artinya dosa melahirkan maut sebab ketika dosa itu sudah matang atau dewasa. Kata yang dipakai adalah $\dot{\alpha} \pi \circ \tau \varepsilon \lambda \varepsilon \sigma \theta \varepsilon i ̃ \sigma \alpha / \alpha \pi \circ \kappa \sigma \varepsilon \omega$ yang artinya melahirkan atau menjadikan. Ketika dosa sudah matang ia dapat tidak dilawan lagi karena manusia yang berdosa sudah senang dengan dosa itu, sudah menyerahkan diri sepenuhnya kepada maut (lih. Roma 6:23; 7:5). Bila keadaannya seperti itu, tentu saja dosa-dosa itu mendatangkan kebinasaan "Sebab upah dosa adalah maut." Maut di sini mengandung arti terpisah dari Allah untuk selama-lamanya.

\section{Penyebab Pencobaan}

Godaan dan ujian yang dihadapi orang percaya merupakan kesempatan untuk pencobaan dan bukan penyebab dari pencobaan. Ujian dan godaan yang datang dari luar (ekstern) dapat menjadi penyebab pencobaan dalam diri manusia (Scheunemann 2013). Maksudnya pencobaan tidak datang dari Allah, tetapi pencobaan datang dari diri manusia sendiri karena sudah dipikat oleh keinginannya. Seseorang berani menghadapi pencobaan ketika melihat pencobaan sebagai alat yang akan menunjukkan ketahanan iman. Di sini dalam proses pertumbuhan iman setiap orang percaya, peran cobaan dan ujian sangat penting yaitu untuk mengukur bagaimana ketahanan dan kesabaran seseorang dalam 
menghadapi setiap cobaan dan ujian yang datang dari luar. Namun perlu diperhatikan bahwa bukanlah Allah di balik setiap cobaan dan ujian yang di hadapi setiap orang beriman.

\section{Allah Bukan Penyebab Pencobaan}

Allah yang kudus bukan sumber dari setiap pencobaan dan masalah yang hadapi oleh semua manusia. Dengan tegas Yakobus berkata "Apabila seorang dicobai, janganlah ia berkata: "Pencobaan ini datang dari Allah!" Sebab Allah tidak dapat dicobai oleh yang jahat, dan Ia sendiri tidak mencobai siapapun” (Yak. 1:13). Anggapan manusia bahwa Allah mencobai manusia untuk kejahatan merupakan bentuk penghujatan terhadap Allah. (Scheunemman 2013).

Yakobus mulai dengan menentukan bahwa pencobaan itu pasti tidak berasal dari Allah melainkan dari dalam diri manusia karena sudah diseret oleh keinginannya sendiri. Tetapi Tuhan menghendaki supaya setiap orang percaya dapat bertahan dalam pencobaan dan melihat pencobaan sebagai ujian untuk dapat mendewasakan kerohaniannya. Pencobaan adalah sarana yang disediakan Allah bagi setiap manusia untuk menyempurnakan dan mendewasakan iman seseorang. Hal ini menegaskan bahwa Allah bukan penyebab dari pencobaan dan ujian iman bagi seseorang karena Allah tidak dapat di cobai oleh sesuatu yang jahat.

\section{Pencobaan Berasal Dari Keinginan Diri Sendiri}

Pencobaan bukan berasal dari Allah, karena Allah tidak dapat di cobai oleh siapapun dan Allah tidak mencobai siapapun. Allah adalah sumber dari segala sesuatu yang dapat mengubah pencobaan menjadi kebahagiaan. Yakobus 
menjelaskan dalam ayat 14 bahwa "tiap-tiap orang dicobai oleh keinginannya sendiri”. Pencobaan berasal dari keinginan diri manusia sendiri karena diseret dan dipikat oleh keinginan. Manusia jatuh ke dalam dosa dan pencobaan karena keinginan jahat yang disertai dengan perilaku, karena menuruti keinginan sendiri tidak menuruti kehendak Allah sehingga akibatnya adalah kematian. (Wiersbe 2008).

Setiap orang percaya harus memahami bahwa Allah adalah kasih. Karena kasih-Nya, Allah menciptakan manusia supaya Dia dapat berbagi kasih kepada ciptaan-Nya, juga agar manusia dapat mengagumkan Dia. Ia menghendaki manusia tetap di dalam hati dan kasih-Nya. Namun seringkali oleh karena pencobaan yang dialaminya menjadikan manusia itu menjauh dari Allah. (Ware 1986). Akibatnya manusia menganggap bahwa Allah ada di balik pencobaan.

Dengan demikian seperti di jelaskan oleh Matthew Henry bahwa manusia tidak dapat menyalahkan Allah jika dia mengalami pencobaan. Jangan sampai manusia berkata, ketika dia mengalami pencobaan atau godaan penyebabnya dari Allah sebab Allah tidak dapat dicobai dengan kejahatan. (Henry 2016).

Sebab hal-hal yang berasal dari Allah pastilah memiliki terang kehidupan. Sebaliknya semua yang ada di dalam dunia yakni keinginan daging, keinginan mata dan keangkuhan hidup berasal dari dunia bukan berasal dari Allah (1 Yohanes 2:16). Hawa nafsu itu memiliki daya yang kuat untuk menyeret dan memikat manusia (Yakobus 1:14) dan jikalau manusia terseret dan terpikat oleh keinginan sendiri akan melahirkan dosa. (Hendi 2018). 


\section{Pencobaan Mengakibatkan Dosa yang Melahirkan Kematian}

Scheunemann menjelaskan bahwa reaksi berantai akan terjadi dalam diri manusia ketika ia menanggapi godaan yang ada. Reaksi ini akan sulit dihentikan. (Scheunemann 2013). Yakobus menjelaskan hal ini dalam ayat 15 dengan kata $\sigma v \lambda \lambda \alpha \beta$ ṽ $\sigma \alpha$, yang artinya mengandung. Seperti seorang perempuan yang mengandung bayi di dalam rahimnya. Ia terlebih dahulu menerima proses pembuahan lalu janin tumbuh dalam rahimnya karena mendapatkan makanan, hingga akhirnya lahir ke dalam dunia.

Demikian pula halnya dosa. Ketika seseorang terseret, terpikat, dan menerima dosa ke dalam pikiran dan hatinya, memberinya makan, dan mendorongnya sehingga menjadi keinginan yang memperbudak, hingga akhirnya melahirkan dosa yang mendatangkan kematian. (Gulo 2017). Hendi dan Aruan menggambarkan proses lahirnya dosa dan maut sebagai berikut: Godaan iblis $\rightarrow$ Nous $\rightarrow$ Lemari batin $\rightarrow$ Id $\rightarrow$ Logismoi $\rightarrow$ Keinginan daging/nafsu $\rightarrow$ menyeret dan memikat $\rightarrow$ Dosa $\rightarrow$ Maut. (Hendi dan Aruan 2020). Sementara Coniaris menjelaskan proses lahirnya dosa sebagai berikut:

Pertama, pikiran menerima saran atau stimulasi. Jika pikiran penuh perhatian, ia akan melihat provokasi dan akan menutup pintu padanya. Kedua, Jiwa akan berbicara dengan saran dan memberikan persetujuannya (seperti yang dilakukan Hawa dengan ular), yang kemudian menjadi berdosa karena menyetujui pikiran dengan senang hati. Ketiga, Ada penyatuan atau penggabungan dengan pemikiran di mana pikiran menyerahkan diri pada saran dan mulai memikirkannya. Keempat, Pikiran menjadi tawanan oleh pemikiran itu karena berulang kali. Kelima, Akhirnya manusia jatuh sepenuhnya sehingga tidak lagi bebas untuk menolaknya sehingga sudah menjadi sebuah keinginan manusia dan memperbudak dirinya sendiri (Coniaris 1998, 96). 
Pikiran yang jahat ini akan memunculkan keinginan atau nafsu (lust; passion; epithumia) yang jahat dan jika keinginan itu dibuahi, maka akan melahirkan dosa (Yakobus 1:14-15). Artinya jika keinginan jahat itu di turuti, maka akan melahirkan dosa. (Hendi 2018). Proses lahirnya dosa adalah sebuah dorongan seperti seorang penjual mengetuk di pintu rumah. Jika seseorang membiarkannya masuk, dia mulai berbicara menawarkan tentang penjualan dagangannya, dan sulit untuk menyingkirkannya bahkan jika seseorang mengamati bahwa dagangannya tidak baik. Dengan demikian harus mengikuti persetujuan dan akhirnya membeli, seringkali bertentangan dengan kehendak sendiri. (Coniaris, 1998). Dengan demikian, dosa bekerja dengan cara memberikan stimulasi ke dalam pikiran seseorang hingga orang itu menjadi tawanannya. Kemudian pikiran orang tersebut akan diperbudak sehingga ia tidak bisa lagi menolak keinginan dosa.Rasul Paulus menuliskan bahwa upah dosa adalah maut. (Roma 6:23). Artinya dosa itu hanya layak mendapatkan kematian karena dosa memisahkan manusia dari Allah sumber kehidupan sejati. (Hendi 2017).

Dosa merupakan sebuah tragedi, di mana umat manusia mengabaikan relasi dengan Allah dan berbalik pada dirinya sendiri, menjadikan dirinya pusat dan berusaha memperoleh penebusan yang terpisah dari rencana keselamatan Allah. (Layantara 2018). Sebab itu seperti diserukan Nicodemos, hendaknya orang percaya menjaga semua indera yang disebut sebagai pintu gerbang menuju dosa. Begitu dia masuk melalui salah satu indera seseorang karena kurangnya 
kewaspadaan seseorang, maka dia menyerang seseorang lebih jauh dengan panahnya sendiri (Coniaris 1998).

\section{Pencobaan Mendatangkan Kehidupan Sempurna dan Kudus}

Pencobaan dapat mendatangkan kehidupan yang semakin kudus, apabila manusia dapat bertahan dalam cobaan dan ujian iman. Dalam ayat 12 dijelaskan bahwa orang yang mengasihi Allah akan tahan uji. Kepada mereka akan diberikan mahkota kehidupan. Seseorang yang tahan uji memberi kesempatan baginya untuk memperoleh kehidupan kekal di masa yang akan datang. (Wall 1997). Kata "mahkota kehidupan" merupakan kiasan dari kehidupan kekal yang diberikan sebagai anugerah semata-mata dari Allah kepada mereka yang tahan uji (Wiersbe 1999).

Tahan uji dalam pencobaan juga akan membawa seseorang ke dalam hidup yang kudus. Ia akan terus berjuang menjauhi dosa, berada dalam kekudusan, menyenangkan dan memuliakan Allah. (Coniaris 1998). Ia akan berupaya dan berlatih untuk tetap berkenan di hadapan Allah yang Mahakudus. Semua tindakannya sesuai dengan kekudusan. Ia membuang semua yang menghalangi kekudusan. Ia menjaga kekudusan dan bergantung penuh kepada Allah. (Hakh 2014). Untuk mencapai kekudusan seseorang akan melewati suatu proses pemurnian jiwa (Roma 12:2) dan tubuh (Roma 2:1).

\section{KESIMPULAN}

Menurut Yakobus 1:12-15, pencobaan tidak berasal dari Allah tetapi dari diri sendiri karena terseret oleh keinginan diri sendiri. Akibat lebih menuruti 
keinginan diri sendiri dari pada kehendak Allah manusia akan masuk ke dalam dosa yang melahirkan kematian. Namun pencobaan juga dapat membuat seseorang bertahan dan berpengharapan di dalam Allah sehingga semakin dewasa dalam iman serta mendatang kehidupan kudus di hadapan Allah apabila terus bertahan dan bersabar dalam pencobaan.

Dengan demikian dalam menghadapi pencobaan orang percaya dituntun untuk selalu waspada dan berjaga-jaga dalam setiap cobaan yang datang sehingga tidak membiarkan dirinya terpikat dan terseret oleh pekerjaan si iblis. Berjagajaga dengan berdoa serta membaca firman Allah akan mendatangkan iman yang teguh dalam melawan dosa

\section{DAFTAR PUSTAKA}

Arifin, Suriani Sukowati. 2019. "Hikmat Menurut Kitab Yakobus." Diligentia: Journal of Theology and Christian Education 1 (1): 15-24.

Coniaris, Anthony M. 1998. Philokalia: The Bible of Orthodox Spirituality. Minneapolis: Light \& Life Pub Co.

Gulo, Manase. 2017. "IMPLEMENTASI KAJIAN BIBLIKAL UNGKAPAN BERBAHAGIALAH ORANG YANG BERTAHAN DALAM PENCOBAAN BERDASARKAN YAKOBUS 1:12-15." Manna Rafflesia 3 (2).

Gunning, J.J.W. 2009. TAFSIRAN ALKITAB: SURAT YAKOBUS . Jakarta: BPK Gunung Mulia.

Hakh, Samuel Benyamin. 2014. "Kuduslah Kamu Sebab Aku Kudus (1 Petrus 1:16)." Sola Experientia 2 (2): 124-43.

Hendi, H. 2015. 50 Buah Pikiran: Sebuah Kajian Teks Perjanjian Baru. Yogyakarta: Lumela.

2018. Formasi Rohani: Fondasi, Purifikasi \& Deifikasi. Yogyakarta: Leutikaprio.

- 2019. Inspirasi Kalbu 3. Yogyakarta: Leutikaprio.

Hendi, H, dan Tiopan Aruan. 2020. "Konsep Manusia Baru Di Dalam Kristus Berdasarkan Surat Efesus 4:17-32.” Evangelikal: Jurnal Teologi Injili dan 
Pembinaan Warga Jemaat $4 \quad$ (1): 113-30. https://doi.org/10.46445/ejti.v4i1.154.

Henry, Matthew. 2016. Surat Ibrani, Yakobus, 1 \& 2 Petrus, 1-3 Yohanes, Yudas, Kitab Wahyu. Surabaya: Momentum.

Jura, Demsy. 2017. "MENGENAL PENULIS KITAB YAKOBUS DAN PENGAJARANNYA." Shanan Jurnal Pendidikan Agama Kristen 1 (1): 158-78.

Layantara, Jessica Novia. 2018. "KEMESTIAN DOSA DALAM INKARNASI KRISTUS." Jurnal Amanat Agung 14 (1): 108-34. https://doi.org/10.47754/jaa.v14i1.44.

Scheunemman, Reinner. 2013. Tafsiran Yakobus Iman dan Perbuatan Menjadi Pelaku Firman dan Bukan Hanya Pendengar. Yogyakarta: Andi.

Susanto, Hasan. 2009. Surat Yakobus Berita Perdamaian Yang Patut Didengar. Malang: Literatur SAAT.

Wall, Robert W. 1997. The New Testament In Context Community of the Wise: The Letter Of James. Valley Forge, Pennsylvania: Trinity Press International.

Ware, Kallistos. 1986. Orthodox Way. America: St. Vladimir's seminary press crestwood.

Widjana, Doreen. 1995. Kupasan Firman Allah Surat Yakobus. Bandung: Yayasan Baptis Indonesia.

Wiersbe, Warren W. 1999. Dewasa di Dalam Kristus Tafsiran Surat Yakobus. Bandung: Kalam Hidup.

2008. Kuat Didalam Kristus: Allah dapat mengubah Pencobaan Yang Anda Alami Menjadi Kemenangan. Bandung: Yayasan Kalam Hidup. 